PAPER

\title{
Reflections on learning and teaching medical ethics in UK medical schools
}

\section{Correspondence to} Professor Gordon M Stirrat, Centre for Ethics in Medicine, University of Bristol, Canynge Hall, 39 Whatley Road Bristol BS8 2PS, UK;

g.m.stirrat@bristol.ac.uk

Received 27 August 2014 Revised 22 September 2014 Accepted 30 September 2014

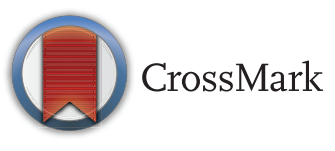

To cite: Stirrat GM. J Med Ethics 2015;41:8-11.

\section{ABSTRACT}

The development of learning, teaching and assessment of medical ethics and law over the last 40 years is reflected upon with particular reference to the roles of the London Medical Group, the Society for the Study of Medical Ethics, its successor Institute of Medical Ethics; the Journal of Medical Ethics and the General Medical Council. Several current issues are addressed. Although the situation seems incomparably better than it was 40 years ago, the relatively recent events in Mid Staffordshire National Health Service (NHS) Foundation Trust show we cannot be complacent. Whatever role we have in the NHS or medical education, we must all strive to make sure it never happens again.

\section{HOW THINGS WERE}

My personal experience concurs with that of Calman: 'the medical ethics curriculum in the 1960s-is well described; essentially there was very little and what there was could be best described as the rules of etiquette for doctors'. ${ }^{1}$ Medical ethics, in the sense that students learn how to conduct themselves, is necessary but not sufficient. The complementary meaning of 'the study of ethical problems raised by medical practice' is fundamental. ${ }^{2}$ Pless reported in 1967 that 'there is no formal teaching on moral problems in UK medical schools and discussions on ward rounds are necessarily very limited'. ${ }^{3}$ Regrettably, the Royal Commission on Medical Education (1965-1968) failed to address this problem ${ }^{4}$ and there was active opposition to the inclusion of medical ethics in the curriculum. One respondent to a General Medical Council (GMC) survey in 1975-1976 wrote: 'While Medical Ethics is very important it would seem ludicrous to put this into the curriculum as a separate subject-It is quite clear that a good clinical teacher will be constantly discussing ethical problems and for this reason I see no point whatever in having it as a separate subject in an already overcrowded curriculum. ${ }^{5}$ Pellegrino, however, was clear that 'ethics can indeed be taught-it deals with concrete judgments in situations in which action must be taken despite uncertainty. It is hard to see how a discipline that aims to make ethical decisions more orderly, systematic and rational, could be deleterious or how leaving everything to sentiment or feeling could be preferable'. ${ }^{6}$

\section{HOW THINGS DEVELOPED}

As Shotter wrote, 'during the second half of the twentieth century, an explosion of medical knowledge coincided with an epoch of rapid social change. In Britain, as elsewhere in Europe, the moral certainties of the early years of the century were increasingly questioned or abandoned, while the deferential society was being eroded. The privileged position of the professional, which accorded the doctor a place in the social hierarchy largely above criticism, began to change'. ${ }^{1}$ But from where was our guidance to come if it we were not learning it from our medical schools or professional bodies?

\section{The London Medical Group}

Founded in 1963 by Rev Edward ('Ted') Shotter, the London Medical Group (LMG) provided part of the answer. Its history, way of working and contributions to the field of medical ethics are well told elsewhere. ${ }^{1}{ }^{78}$ The LMG harnessed the interest, energy and intellect of medical students and junior doctors. Students were given the freedom to reflect on medical practice and identify important topics not covered by the medical syllabus of the time. Seminars and conferences provided an interdisciplinary forum for the discussion of issues such as palliative care, child abuse and iatrogenic disease, long before they had found their way on to the medical curriculum. Although not always the specific focus, medical ethics was often central to many of the issues discussed. ${ }^{9}$

Ultimately, Medical Groups were established in 17 other UK Medical Schools. For Campbell, their great strength was that they recognised clinical reality and were always firmly grounded in clinical medicine. ${ }^{1}$ Although Kennedy thought the Medical Groups were a 'wonderful innovation', he was concerned that they preached only to the converted, were 'a bit inward looking' and unsystematic. ${ }^{1}$

Several of the students who played leading roles in the Medical Groups became key people in the continuing development of Medical Ethics in the UK. A medical postgraduate 'Society for the Study of Medical Ethics' (SSME) was established in 1972 by recently qualified former LMG students 'to influence both professional and public discussion of the moral consequences of medical practice; to ensure that this developing subject achieved a proper autonomy and that multidisciplinary discussions were not unduly influenced by any one of the non-medical interests'. ${ }^{10}$

The founding in 1976 of a centre of medical law and ethics at King's College London by Professor (now Sir Ian) Kennedy was another landmark for postgraduate studies in medical ethics and an early example of the symbiosis between these disciplines. 


\section{The Journal of Medical Ethics}

How the SSME came to publish the Journal of Medical Ethics, its aims and subsequent history are well described in this $40^{\text {th }}$ anniversary edition and elsewhere. ${ }^{10-13}$

In an early editorial, Campbell wrote 'What the future of courses in medical ethics should be is as yet far from clear. Upon what theoretical assumptions does the subject proceed? What methods are appropriate for teaching it? What is the optimum point for inclusion in the medical curriculum? Who should teach it? What objectives are aimed at, and how are these to be assessed? ${ }^{14}$ We have struggled with these ever since.

The journal has long enjoyed a high impact factor and its contribution to the development of the teaching of medical ethics has been very significant.

\section{The GMC and medical ethics}

Among the 34 schools that responded to a GMC survey of medical education in the UK and Ireland in 1975-1976, ${ }^{5} 25$ included ethics formally in the curriculum; nine had no plans to do so; and four believed strongly that it would be 'wrong to attempt any formal teaching since ethics is not a subject and cannot be taught by definition'. In its 1980 Recommendations on Basic Medical Education, the GMC Education Committee wrote 'Instruction should be given in the principles of medical ethics, and in the functions of the General Medical Council. While some aspects of medical ethics can be dealt with appropriately by systematic instruction, the council considers that day-to-day teaching, particularly in the clinical context is of greater importance'. 15

\section{The Pond Report}

In 1984, a working party convened by the Institute of Medical Ethics (IME) reviewed current practice in teaching medical ethics in UK medical schools. The Pond Report is, arguably, the most influential publication on the teaching of medical ethics of my generation..$^{1} 216$ It suggested, for example, that medical ethics should be taught at regular intervals throughout the medical course: clinical teaching of ethics should normally begin from clinical examples and small group discussion should be emphasised; interested medical teachers should be encouraged and assisted to undertake further study; multidisciplinary ethics teaching should be encouraged; care should be taken to ensure that teaching is not undertaken by those who hold particular views and promote a personal agenda; examinations and other assessments should have an ethics component: and elective courses should be arranged for interested students. ${ }^{2}$ They (perhaps regrettably) decided not to propose a specific syllabus for medical ethics teaching.

Burling et al examined the influence of the Pond Report on the teaching of medical ethics in the London Medical Schools. Ethics was being taught in all but two of the 12 schools and in one of those it was being introduced. In all but one school, the students felt that the ethics teaching was as claimed by their school but attendance at optional courses was poor. However, only one London school and two relatively recently established provincial schools had systematic and integrated courses. ${ }^{17}$ Fifteen years later, a report commissioned by the IME found that, although medical ethics and law were represented in the curricula of the 22 (of 28) UK medical schools that responded, significant concerns remained about the status, content, delivery and assessment of the teaching of ethics and law. ${ }^{18}$ Preston-Shoot and McKimm have more recently reinforced these concerns about law teaching and assessment. ${ }^{19}$

\section{The Institute of Medical Ethics}

In 1984, the SSME became the IME to 'raise ethical standards in clinical practice, not by prescribing those standards, but by promoting dialogue, teaching and research in medical ethics'. 9 It organises conferences, provides grants to students interested in medical ethics and works to develop medical ethics and law teaching in UK medical schools. It has been highly influential in the development of teaching and learning of medical ethics and law through the Pond Report, ${ }^{2}$ the consensus statement by teachers of medical ethics and law in UK medical schools, ${ }^{20}$ and an updated indicative core content of learning for medical ethics and law in UK medical schools that is consistent with the GMC's guidance on undergraduate education. ${ }^{21}$

Through its membership, the IME aims 'to create and support a network of clinicians, students and academics who share its core values and in so doing engage with a much wider audience' and 'build a robust medical ethics community to face the challenges of 21st century healthcare'. ${ }^{9}$ More information is available online (http://www.instituteofmedicalethics.org).

\section{The GMC and Tomorrow's Doctors}

In addition to its statutory role of registering and regulating the medical profession in the UK, the GMC holds medical schools responsible for standards in medical education set down in Tomorrow's Doctors. ${ }^{22}$ However, 'each medical school is free to design its own curriculum to suit its own circumstances, consistent with Tomorrow's Doctors'.22

In the 1993 version of Tomorrow's Doctors, the GMC stated 'graduates must know about and understand the main ethical and legal issues they will come across'. ${ }^{23}$ The 2009 version expanded this by requiring that the graduate be able to behave according to ethical and legal principles and know about and keep to the GMC's ethical guidance and standards. Medical schools must ensure that every graduate has achieved all the outcomes set out in Tomorrow's Doctors. ${ }^{22}$ The GMC's quality assurance mechanisms for medical education include detailed reports submitted by, and visits to, medical schools. However, in 15 of 22 UK medical schools who responded to a survey in 2004, it was possible for students to fail ethics assessments and still graduate. ${ }^{18}$ If the standards set down in Tomorrow's Doctors $^{22}$ are enforced that should not be possible today: but how well the GMC's assessors are equipped properly to assess learning, teaching and assessment of medical ethics and law is, I believe, still open to question.

\section{CURRENT AND PERSISTENT ISSUES \\ Assessing students}

The GMC requires medical schools to ensure that 'students' moral and ethical reasoning, attitudes and behaviour as well as knowledge of laws relevant to medical practice conform to the standards set out in Tomorrow's Doctors' ${ }^{22}$ This requires both formative and summative assessment but what should be assessed, when and how are still hotly debated. ${ }^{24-27}$

In 2013, the IME produced a practical guide for the assessment of medical ethics and law to complement the core content of learning. ${ }^{21}$ It provides examples of methods of assessment and some pointers for deciding what methods might be appropriate for particular learning outcomes. ${ }^{27}$ An online version of this document and further examples of teaching, learning and assessment methods are available on the IME website (http:/ www.instituteofmedicalethics.org). It is the intention that the core content and the guide to its assessment be continually updated through the IME website. 


\section{Does teaching and learning of medical ethics and law make a difference?}

Campbell et $a l^{28}$ conclude that there is paucity of good evidence, conflicting findings and major design problems. It is almost impossible to design and fund a quantitative research study of sufficient power even if the attributes to be tested could be agreed upon. ${ }^{6}$

Pellegrino pointed out that data of this kind are lacking for other subjects in the medical curriculum. There is, for example, 'no proven correlation between the teaching of anatomy or biochemistry and the scientific quality of a physician's practice'. ${ }^{6}$ This must not breed complacency and well designed, collaborative and iterative qualitative research may be a better option (though not easy to fund).

\section{The hidden curriculum and role models}

Given the immanence of ethics in all medical interventions, much of what our students learn comes from what they see in clinical practice in all its diversity. All doctors have experienced for good or ill the pervasive influence of this 'hidden curriculum' in their training. ${ }^{29-31}$ 'Without careful and explicit attention to character, students are likely to absorb unacceptable habits and attitudes through the silent curriculum of observing medical misconduct and mistakenly adopting that as the norm'. 31 'Teaching the teachers' is one means by which the positive effects of this hidden curriculum can be accentuated and the negative effects reduced. ${ }^{21}$

\section{Further enabling our graduates to 'do good medical ethics'}

Learning and teaching of medical ethics, law and other cognate disciplines are incomparably better than they were 40 years ago. ${ }^{9}$ However, much still needs to be done to achieve the above objective. In addition to suggestions discussed earlier, among the issues to consider are:

- Formal syllabuses such as the 2010 'Core Content of Learning' may lead to teachers and students treating them as rules without thinking about, or reflecting critically on, them in the clinical context. This undermines the aims of teaching medical ethics and law that recognise that ethics is a necessary part of all clinical encounters and medical and public health interventions. ${ }^{21}$

- Rational and systematic approaches to teaching medical ethics and law tend to ignore emotional responses of the patient, student and teacher. To counter this, Gillam et al, for example, use narrative ethics which considers personal experiences and emotional responses to them. ${ }^{32}$ We also need to be more aware of cultural pluralism among our students, teachers and patients so that students learn to work with colleagues and care for patients who have a different world view.

- There continues to be resistance by those responsible for education in medical schools to 'load more on to the curriculum'. This is understandable and dealing with it is complex given the almost impregnable autonomy of each school over its curriculum. Perhaps the IME could work more closely with, for example, the Association of the Study of Medical Education, the Association of Medical Humanities, the UK Council for Clinical Communication Skills Teaching in Undergraduate Medical Education and Behavioural \& Social Sciences Teaching in Medicine to help medical schools properly to integrate these disciplines horizontally and vertically in curriculum without overburdening it?
- Teachers need to become more 'savvy' about the effective use of digital technologies. Students also need clear guidance about the ethics of their use. This is the focus of the IME's annual conference in 2015 (see http://www. instituteofmedicalethics.org).

- Medical ethics has become part of bioethics. On one hand, this has led to the subject being recognised as a rigorous academic discipline and progress in teaching and learning medical ethics and law could not have happened or continue without the close involvement of, for example, lawyers, social scientists, philosophers and theologians as well as doctors. On the other, non-medical bioethicists sometimes fail to grasp clinical realities and clinicians feel inadequate, making them apprehensive about getting involved in formal ethics teaching.

- The increasing work pressures on clinicians in the National Health Service (NHS) mitigate against structured involvement in teaching medical ethics.

- These again emphasise the need to 'teach the teachers'. We should also help to develop the careers of the increasing number of graduates who took a special interest in medical ethics as students.

\section{CONCLUSIONS}

We must never become complacent. The dreadful events in Mid Staffordshire NHS Foundation Trust between 2005 and 2009 took place when 'the quality of care was subject to more inspection and regulation than ever before and doctors had unprecedented access to guidance on ethical practice'. 9 Among the many 'problems identified but not addressed effectively' were: a lack of urgency; figures preferred to people; a focus on systems not outcomes; those who received care were not listened to; insufficient attention to professional standards; lack of support for staff; and a weak professional voice in management decisions. ${ }^{33}$ It behoves us all to ponder how such things could have happened and, whatever our role in the NHS or medical education, strive to make sure they never happen again.

We must beware of easy answers but it is encouraging that, in addition to the teaching and learning of medical students, medical ethics is one of the competency domains in the foundation years' curriculum and is becoming an increasingly common feature in specialty exit examinations. ${ }^{9}$

Competing interests GMS is Honorary Vice-president of the IME, co-owner of the Journal of Medical Ethics.

Provenance and peer review Commissioned; internally peer reviewed.

\section{REFERENCES}

1 Reynolds LA, Tansey EM, eds. Medical ethics education in Britain, 1963-1993. The Wellcome Trust Centre for the History of Medicine at UCL, 2007.

2 Boyd KM, ed. Report of a working party on the teaching of medical ethics. London: IME Publications Ltd., Sir Desmond Pond, Chairman, 1987.

3 Pless IB. Teaching medical ethics - empirical or rational? Brit J Med Educn 1967;1:290-3.

4 Royal Commission on Medical Education. Report, Cmnd 3569. London: HMSO. Lord Todd, Chairman, 1968

5 General Medical Council. Survey of basic medical education in the British Isles. London: Nuffield Provincial Hospitals Trust, 1977.

6 Pellegrino ED. Teaching medical ethics: some persistent questions and some responses. Acad Med 1989;64:701-3.

7 Barr M. Clinical ethics teaching in Britain: a history of the London Medical Group. New Rev Bioeth 2003;1:73-84.

8 Shotter $\mathrm{E}$, Lloyd $\mathrm{M}$, Higgs $\mathrm{R}$, et al. Fifty years of medical ethics: from the London Medical Group to the Institute of Medical Ethics. J Med Ethics 2013:39:662-6.

9 Kong WM, Vernon B. Harnessing the LMG legacy: the IME's vision for the future. J Med Ethics 2013:39:669-71.

10 Shotter $E$. A retrospective study and personal reflection on the influence of the Medical Groups. In: Reynolds LA, Tansey EM, eds. Medical Ethics Education in 
Britain, 1963-1993. The Wellcome Trust Centre for the History of Medicine at UCL, 2007 Appx 1:96.

11 Editorial. The discussion of moral issues. J Med Ethics 1975;1:1.

12 Campbell AV, Gillon R, Savulescu J, et al. The Journal of Medical Ethics and Medical Humanities: offsprings of the London Medical Group. J Med Ethics 2013;39:667-8.

13 Campbell AV. The formative years: medical ethics comes of age. J Med Ethics 2015;41:5-7.

14 Editorial. Teaching medical ethics. J Med Ethics 1975;1:55.

15 Crisp AH. The General Medical Council and medical ethics. J Med Ethics 1985;11:6-7.

16 Gillon R. Medical ethics education. J Med Ethics 1987;13:115-16.

17 Burling SJ, Lumley JSP, McCarthy LSL, et al. Review of teaching of medical ethics in London Medical Schools. J Med Ethics 1990;16:206-9.

18 Consensus Group of Teachers of Medical Ethics and Law in UK Medical Schools. Teaching medical ethics and law within medical education: a model for the UK core curriculum. J Med Ethics 1998;24:188-92.

19 Mattick K, Bligh J. Teaching and assessing medical ethics: where are we now? J Med Ethics 2006;32:181-5.

20 Preston-Shoot M, McKimm J. Prepared for practice? Law teaching and assessment in UK medical schools. J Med Ethics 2010;36:694-9.

21 Stirrat GM, Johnston C, Gillon R, et al. Teaching and learning ethics: medical ethics and law for doctors of tomorrow: the 1998 Consensus Statement updated. J Med Ethics 2010;36:55-60.

22 General Medical Council. Tomorrow's doctors: outcomes and standards for undergraduate medical education. London: GMC, 2009.
23 General Medical Council. Tomorrow's doctors: outcomes and standards for undergraduate medical education. London: GMC, 2003.

24 Eckles RE, Meslin EM, Gaffney M, et al. Medical ethics education: where are we? Where should we be going? A review. Acad Med 2005;80:1143-52.

25 Dowie A. Making sense of assessment in medical ethics and law. J Med Ethics 2014;40(10):717-18.

26 Wass V. Medical ethics and law: a practical guide to the assessment of the core content of learning. J Med Ethics 2014:40:721-2.

27 Fenwick A, Johnston C, Knight $\mathrm{R}$, et al. Medical Ethics and Law: A practical guide to the assessment of the core content of learning. A report from the Education Steering Group of the Institute of Medical Ethics. London: The Institute of Medical Ethics, 2013:1-48.

28 Campbell AV, Chin J, Voo TC. How can we know that ethics education produces ethical doctors? Med Teach 2007;29:431-6.

29 Hafferty FW, Franks R. The hidden curriculum, ethics teaching and the structure of medical education. Acad Med 1994;69:861-7.

30 Campbell AV, Chin J, Voo TC. Ethics and attitudes. In: Dent JA, Harden M, eds. A practical guide for medical teachers. London, UK: Churchill Livingstone, 2009:274-80.

31 Rhodes R, Cohen DS. Understanding, being, doing: medical ethics in medical education. Camb Q Healthc Ethics 2003;12:39-53.

32 Gillam L, Delany C, Guilleman M, et al. The role of emotions in health professional ethics teaching. J Med Ethics 2014;40:331-5.

33 Francis R. Report of the Mid Staffordshire NHS Foundation Trust Public Inquiry. London: The Stationery Office, 2013. 